\title{
Сейтметова Ж.Р.
}

Казахский национальный университет имени аль-Фараби, Республика Казахстан, г. Алматы, e-mail: seitmetovaj@gmail.com

\section{НАЦИОНААЬНЫЙ ГЕРОЙ В ТРАКТОВКЕ ЕГИПЕТСКОГО АРАМАТУРГА ААЬФРЕАА ФАРАГА}

В статье рассматривается интерпретация исторического сюжета известным египетским Араматургом Альфредом Фарагом. Цель исследования - раскрыть художественное и содержательное своеобразие пьесы «Сулейман аль-Халаби» в трактовке роли личности в истории. В процессе исследования было выявлено, что автор через образ главного героя раскрывает свое понимание таких категорий, как справедливость и истина. К художественным особенностям Арамы относятся монтажная композиция сюжета, прием «актерской импровизации», мицедейства, элементы «театра в театре», театральной формы «самира».

Ключевые слова: А^ьфреА Фараг, Сулейман а^ь-Халаби, драма, пьеса, египетский театр.

$$
\begin{gathered}
\text { Сейтметова Ж.Р. } \\
\text { әл-Фараби атындағы Қазақ, ұлттық, университеті, Қазақстан Республикасы, Алматы қ., } \\
\text { e-mail: seitmetovaj@gmail.com }
\end{gathered}
$$

Египет драматургі альфред фарагтың баяндауындағы ұлттық кейіпкер

Мақаяада белгілі Египет драматургі Альфред Фарагтың тарихи сюжетті баяндауы қарастырылады. Зерттеу мақсаты - тұлғаның тарихтағы ролін айқындаудағы «Сулейман аль-Халаби» пьесасының көркемдік және мазмұндық ерекшелігін зерделеу. Зерттеу барысында автордың бас кейіпкер образы арқылы әділдік пен ақиқат деген категорияларды өзіндік пайымдауы анықталды. Араманың көркемдік ерекшелігіне сюжеттің монтажды композициясы, «актерлік импровизация», «самир» ойын-сауық, формасы жатады.

Түйін сөздер: А^ьфред Фараг, Сулейман әл-Хәләби, драма, пьеса, Египет театры.

\section{Seitmetova Zh.}

Al-Farabi Kazakh National University, Kazakhstan, Almaty, e-mail: seitmetovaj@gmail.com

The national hero in the according to the viewpoint of egyptian dramatist Alfred Farag

The article presents interpretation of the historical narratives by the famous Egyptian dramatist Alfred Farag. The aim of the research is to open originality of artistic and contextual side of the play (composition) related to interpretation of the role of personality in history. During the research it was identified that the author elucidated his own understanding of such categories as truth and justice by means of main hero's character. The artistic peculiarities of drama: splicing together different story lines, method of «actor's improvisation» and elements of «theater in the theater».

Key words: Alfred Farag, Suleyman al-Halabi, drama, play, Egyptian theater.

\section{Введение}

В мировой драматургии есть немало примеров художественной разработки исторических тем, заимствование сюжетов из исторического прошлого. Стало общим явлением проецирование исторических сюжетов на современность, исследование настоящего через прошлое. В исторических пьесах, в том числе и в тех, где делается особый акцент на мотивах человеческого поведения, на моральных стимулах, побуждающих героя к тем или иным действиям, нередко ставятся самые актуальные вопросы современности. 
Известный египетский драматург А. Фараг (1929-2005), оказавший огромное влияние на развитие современной арабской, египетской драматургии, в своем творчестве неоднократно обращался к истории, к историческим событиям и фактам арабской истории. Драматург через их ретроспективный парафраз излагал свое понимание волнующих его вопросов действительности в определенный исторический период развития страны. Обращаясь к истории, Фараг своей драматургией подтвердил следующее высказывание Т. аль-Хакима: «никогда история, предания, сказания, легенды - все унаследованное от прошлого, не перестанет быть живительным источником для современной литературы. Однако у новой литературы иная миссия. Черпая вдохновение в новом материале, она добивается создания новой формы и передачи новых идей. Улучшай свою среду, живи в ней, служи ее целям - вот девиз современного писателя. Новая литература не регистрирует механически события прошлого. Она наделяет минувшие времена новым духом, дает новую голову старому телу» (Современная арабская литература, 1966:38).

Героика драмы

Одной из известных пьес Альфреда Фарага является драма «Сулейман аль-Халаби» (1962), где автор выразил через историческое содержание основные национальные и общественные проблемы своего времени. Постановка этой пьесы была осуществлена в 1965 году на сцене Национального театра. В основу сюжета пьесы положено подлинное историческое событие - убийство в 1800 г. Сулейманом альХалаби, сирийским юношей, генерала Клебера, командующего французскими войсками, оккупировавшими Египет. При написании пьесы драматург обращается к историческим хроникам Абдрахмана аль-Джабарти, крупнейшего арабского историка рубежа XVIII-XIX вв. (1754-1822), который в частности отмечает, что французы объявили, что османские власти (имеется ввиду Османская Турция, которая 400 лет владычествовала в арабских странах; Египет был более независим, но формально также входил в состав Османской империи) наняли Сулеймана альХалаби за 40 киршей, чтобы он убил военачальника французской армии. Драматург считает это обвинение неубедительным. В предисловии к пьесе, Фараг пишет, что университет аль-Азхар играл всегда важную роль в политической и культурной жизни египтян. Основанный еще в $\mathrm{X}$ веке аль-Азхар на протяжении всей долгой ис- тории выступал как хранитель мусульманских традиций, которые он передавал из поколения в поколение. Этот университет был и остается одним из крупнейших центров мусульманского просвещения в мусульманском мире. Университет занимал важное место в египетском обществе, оказывая на общественную мысль египтян действенное влияние. С одной стороны, он был цитаделью мусульманских богословов, стремившихся сохранить монополию в области просвещения и судопроизводства. С другой стороны, в годы французской оккупации он становился центром антиколониальной активности египтян. И царившая в тот период истории Египта атмосфера борьбы и противостояния не могла не оказать свое воздействие на Сулеймана альХалаби. Как пишет автор: «Может ли кто-нибудь представить, что Сулейман мог действовать изолированно и не иметь связи с тем, что происходило вокруг него. Вряд ли. Вероятнее всего, что между Сулейманом и другими, не известными нам людьми, происходили горячие споры по поводу убийства Клебера. Возможно, в нем участвовали многочисленные силы. Французы, обвинив османские власти в организации убийства, хотели не дать разгореться пламени, бушевавшему в сердцах египтян, особенно молодежи» (AlFarid Farag.Suleiman al-Halabi,1962:10-11). Своим комментарием автор хотел подчеркнуть, что убийство было совершено не в угоду личным интересам, в основе его лежала нравственная, гражданская позиция.

А. Фараг в пьесе «Сулейман аль-Халаби» попытался раскрыть, обнажить причины убийства генерала Клебера, лежащие в сфере общественного, а не только индивидуального сознания героя пьесы. Фараг показывает роль личности, причем личности простого рядового человека в истории, и роль просвещенных слоев общества, интеллигенции в сложные моменты для страны.

А. Фараг в этой пьесе пытается в духе своего времени реабилитировать Сулеймана альХалаби, которого французы рассматривали как террориста и подкупленного убийцу. Автор видит в образе этой исторической личности борца против чужеземных оккупантов. Он горит жаждой мщения за поруганную землю, за тяжелые условия, в которые ввергла французская оккупация египетский народ и выступает против соглашательской политики, осуждая даже азхариотов за умеренное и пассивное сопротивление. Другая идея пьесы заключена в том, что герой ищет правду и справедливость и в своих монологах поднимает морально-этические воп- 
росы, связанные с предательством, лицемерием, ханжеством.

Поиск справедливости - вот проблема, которую ставит писатель через образ своего героя. В основе решения любой проблемы на первом месте должна быть справедливость. Пьеса дает однозначный ответ на вопрос что делать, если родную землю захватили чужеземцы - все методы должны использоваться в борьбе против захватчика. Писатель, исходя из реалий 60 -х годов, когда он писал пьесу, и когда Египту приходилось отражать агрессию Израиля, считает, что против захватчиков должен бороться весь народ, когда речь идет об освобождении Родины. И одиночное выступление Сулеймана аль-Халаби, совершившего подвиг, и борьба азхариотов, выступающих за мирный протест и ненасильственное сопротивление, все должно быть брошено на алтарь освобождения отечества.

Как отмечает египетский литературовед Рага ан-Наккаш, наряду с основной темой пьесы темой индивидуальной борьбы Сулейман альХалаби с французскими оккупантами, «в пьесе через разрозненные сцены, носящие в себе элементы повествования, показана общественноисторическая обстановка, которая предшествует вхождению Сулеймана в круг событий. Через эти элементы повествования мы узнаем о существующих в обществе позициях, об окружающей среде и социально-экономическом положении» (Raga:4).

Из трактовки Фарагом исторического события видно, что автор через образ главного героя раскрывает свое понимание таких категорий, как справедливость и истина. Для него эти категории не абстрактны. Он наполняет их актуальным смыслом, чтобы из них исходить в борьбе против современных колонизаторов и захватчиков. Фараг показал, что убийство Клебера было актом справедливости, что Сулейман аль-Халаби выразил волю народа, который изначально сопротивлялся французским колонизаторам, и убийство генерала - не изолированный террористический акт, а одно из проявлений борьбы народа.

Сулейман находится в постоянном поиске познания. Он не ограничивается тем, что видит насилие и призывает с ним бороться, он верит в торжество разума и осознанного действия. Он не приемлет методы пассивной долгой борьбы, которую предпочитают азхариоты, желающие избежать лишнего кровопролития и жертв, а сознательно в одиночку идет на борьбу со злом, которое олицетворяет генерал Клебер.
А. Фараг не индивидуализирует образ главного героя и не привязывает его к определенному месту, а придает ему некую универсальность, обобщенность. Сулейман подобен героям эпических сказаний. «Его личность раскрывается не как индивидуальная, а скорее как обобщенная, в контексте его эпохи и проливает свет на тревоги самой эпохи. Она имеет значение для любой эпохи, отмеченной насилием и захватом. Поэтому личность Сулеймана аль-Халаби выходит за рамки сугубо личного, и автор представляет нам яркий образ народного движения - движения египетского народа против французского гнета» (Hivar al-Farid Farag lijarida "al-Qabs", 2003:13).

Образ Сулеймана аль-Халаби у драматурга не отличается от образа Халаби, представленного в сочинении историка аль-Джабарти. Автор взял основные черты своего героя от его исторического прототипа. Исторический Халаби отличался храбростью, опрометчивостью, был подвержен эмоциональным порывам. К этим чертам Фараг добавил элементы переживаний и сомнений, перемешанные с бунтом против условий, в которые ввергли иностранные захватчики арабскую страну. Все персонажи и все действие пьесы сосредоточены вокруг личности одного героя, и они направлены на то, чтобы высветить личность этого героя. Личность Халаби несет в себе черты характерные именно для трагедийного героя. В нем борются противоречия, он призывает и сам совершает добрые деяния, но идет на убийство. Сулейман аль-Халаби предстает человеком большой воли, самоотверженности и цельности, искателем истины и защитником справедливости. Но он направляет свою энергию и деятельность на путь одиночного терроризма. Трагизм конфликта творческой личности с действительностью толкает его на роковой шаг. Он остается в пьесе непреклонным в борьбе за свои идеи.

Египетские критики Луис Авад и Рага анНакаш в своих работах указывают на сходство образов Гамлета и Сулеймана аль-Халаби (Hivar al-Farid Farag lijarida "al-Qabs",2003, Aud Luis. Maza yajri fi al-masrah al-mysry. Jarida "al-Ahram”, 1966). Они видят схожесть в трагичности образов, в неумении мириться с несправедливостью, лицемерием, фальшью. И в то же время отмечают большую разницу между двумя героями и заключают, что Сулеймана аль-Халаби толкает на действие не «желание отомстить за себя или своих близких, а единственное желание добиться справедливости; им движет чистый разум, а не обостренное чувство (Hivar al-Farid Farag lija- 
rida “al-Qabs",2003:14). Отличие они видят в том, что у Гамлета личное переживание поднялось до общечеловеческого. Что касается Халаби, то его проблема была изначальна проблемой общества, народа, находящегося под оккупацией.

В трактовке драматурга герои, подобные Сулейману аль-Халаби, возникают на определенных этапах жизни, когда наступает особенный накал жизни и на сцену выступает лидер, зачастую изначально трагедийная личность, сконцентрировавший в себе устремления и настроения многих, и идущий на подвиг или на действие, в какой-то степени меняющее ход событий, и исчезающий в монотонности и суете жизни, для которой он чужд.

Как нам представляется, с точки зрения 60-х годов прошлого столетия, когда писалась пьеса, А. Фараг рассматривает поступок Сулеймана аль-Халаби как подвиг, как проявление борьбы народа. И все же то, что драматург ставит вопрос, правомерен ли насильственный акт в отношении другого человека, после убийства которого на его место придет другой, говорит о том, что Фарага как тонкого художника этот вопрос волновал глубже. Да, акт возмездия обратил внимание мировой общественности на насилие французов в Египте, но уйти из него французов заставили объективные обстоятельства, среди которых немаловажную роль сыграла позиция Англии в этом регионе, который она превратила в свою колонию к концу XIX века.

Художественное своеобразие пьесы

Пьеса Фарага «Сулейман аль-Халаби» это не традиционная драма, фабула которой состоит из последовательной цепи событий, имеющих свою кульминацию, а затем развязку. Напротив, как эпическая пьеса, финал которой заранее известен, она состоит из сцен, которые можно выдвинуть, даже поменять местами. Автор следует принципам «эпического» театра Брехта, «который, в отличие от «драматического», должен возбуждать у зрителей интерес к ходу действия, а не к развязке. Поэтому знание фабулы и развязки наперед должно освободить зрителя от аффектов и лихорадочного беспокойства о судьбе героя и позволить ему, так сказать, «в трезвом уме и твердой памяти» наблюдать за ходом действия, критически взвешивая и оценивая поведение персонажей. Поскольку зритель уже знает, «чем все это кончится», он не будет испытывать того нетерпеливого волнения, которое подчас во время спектакля застилает пеленой его взор и разум» (Брехт, 1963:57).
Хорошо зная законы театра, Фараг при написании пьесы использовал приемы, придающие эффектность и особую напряженность действия. $\mathrm{K}$ художественным особенностям творческого метода драматургии Фарага относится монтажная композиция сюжета, которая ярко воплощена в этой драме. Драматург активно оперирует фрагментами действия, что служит, прежде всего, композиционным эффектам. Так, он обыгрывает прием ввода одной сцены в другую, хотя действие происходит в разное время и с разными персонажами. В пьесе одним из действующих персонажей является хор, сочетающий в себе черты античного хора и рассказчика альхаккавати, персонажа египетских народных представлений. Использование хора - один из приемов театра Брехта, так называемый «эффект отчуждения», «призванный разрушать гипнотическое воздействие театра, не допускать возникновения сценических иллюзий, и, с другой стороны, комментировать события на сцене, оценивать их, способствовать выработке критических суждений публики» (Брехт, 1963:22). У Фарага хор начинает действие с беспристрастного рассказа - своеобразной экспозиции - о тех событиях, которые предшествовали основному действию пьесы - о положении страны, отношении главнокомандующего генерала Клебера к египетскому народу. Свой рассказ хор заключает словами: «И отсюда начинается наш рассказ». Таким приемом, заимствованным у древнегреческого театра, зритель подготавливается к тому, что он увидит дальше. В пьесу Фараг вводит прием «актерской импровизации», лицедейства, элементы «театра в театре», что вызывает ассоциации не только с пьесами Шекспира или Л. Пиранделло, но и с народной театральной формой самир - с его персонажами масками, актерской импровизацией, вовлечением зрителя в театральное действие.

Пьеса написана на литературном арабском языке - аль-фусха и обращение драматурга в пьесе «Сулейман аль-Халаби» к литературному языку объясняется жанром пьесы и ее темой - борьбой против колониализма в масштабе не только Египта, но и всего Арабского Востока, долгое время пребывавшего в колониальной зависимости. Исторический сюжет и пафос антиколониальной борьбы соответственно требовал использования именно литературного языка с его возможностью выразить глубокие идейные и философские размышления. Второй причиной было то, что персонажи пьесы, как сам Сулейман, так и его товарищи по университету, и их ду- 
ховные наставники были самыми образованными людьми в Египте, поскольку аль-Азхар был единственным университетом, где использовали литературный арабский язык и хорошо его знали. Только изредка Фараг вставляет диалектное слово или целое предложение в речь своих персонажей из низов, из необразованной среды.

Проблема использования литературного языка-аль-фусха или разговорного-аль-аммийа, постоянно встает перед арабской драматургией в связи с тем, что аль-фусха является общеарабским языком прессы и литературы, в то время как жители разных арабских регионов говорят между собой на своих диалектах.

А. Фараг по этому поводу пишет: «Я считаю, что разговорный язык годится в качестве языка литературы точно так же, как и аль-фусха - язык широких возможностей. Но я в то же время сохраняю право иметь мнение, что существует большое различие между бессмертным разговорным языком Байрама ат-Туниси и площадным, базарным языком, между литературным Тауфика аль-Хакима, аль-Мазини и Таха Хусейна и литературным в колонке о событиях в любой информационной газете. У языка литературы - все равно фусха или аммийа - свои эстетические, выразительные качества. А у сценического искусства, помимо этих общих для литературы качеств, свои собственные, как у любого искусства слова. Искусство театра предпочитает язык лаконичный, выразительный и ясный, без сложных оборотов, язык, в котором отсутствует многоступенчатые внутренние конструкции. Иначе зритель не сможет вникнуть в смысл того, что говорится со сцены» (Farag, 1966:114).

А. Фараг пытался реализовать свою языковую позицию в своих пьесах, это видно и по пьесе «Сулейман аль-Халаби». Он выбрал для своей исторической пьесы язык, в котором торжественность, величавость аль-фусха сочетается с живостью и текучестью аль-аммийа.

В своих интервью по поводу данной пьесы драматург отмечал, что не ставил перед собой цели точного воспроизведения исторических событий. Он видел свою задачу, прежде всего в создании героического образа патриота, человека, не побоявшегося пойти на большой риск и смерть во имя преданности своим идеалам и убеждениям. В интервью журналу «Аль-Масрах ва синема» Фараг на вопрос: почему вы обращаетесь к истории? Отвечает: «Близкое видится на расстоянии. Мы пишем об истории, чтобы приблизиться к действительности. Я не стремлюсь представлять социальные явления действительности прямо- линейно, и мне важно раскрыть основные противоречия современного египтянина. В нашей литературе нет персонажей подобных Гамлету, Анне Карениной, Карамазову или Отелло. Мы должны создать свои персонажи - национального героя. Если Гамлет представляет собой эпоху Ренессанса, то кто же Сулейман аль-Халаби? Он араб, который выступил против внешнего давления. Он живет в такой же атмосфере тревоги, в какой мы живем сегодня» (Saliha.Az-Zir Hamlet. Majalla “Ruz al-Usuf”.14/1/1991).

Известный российский исследователь В.Н. Кирпиченко пишет по этому поводу: «Возрождение в драматургии интереса к исторической тематике не означало ухода от сегодняшнего дня в прошлое, оно диктовалось потребностью более глубокого осмысления современных проблем и конфликтов путем актуализации их исторического контекста» (Кирпиченко, Сафронов, 2002:118).

\section{Заключение}

Несмотря на отнесенность драматического действия в прошлое, пьеса «Сулейман альХалаби» обращена к настоящему, к постижению сложных историко-политических процессов, происходивших в Египте и, в целом, в арабском мире в 50-60-е годы, в полном соответствии с концепцией драматурга, познающего современность через историю. Герой Альфреда Фарага твердо верит в свои силы, в свою инициативу, в способность добиться поставленной цели. Он проявляет свою сущность в активных поисках и решительной борьбе и цель его служению народу, обществу.

Арабские критики считают, что пьеса, написанная в конце 60-х XX века, до сих пор не теряет своей актуальности, поскольку раздробленность, противоречия, характерные для арабских племен доисламского периода, продолжают иметь место и в настоящее время между народами Арабского Востока (Rania,1998).

Творчески преобразуя мировой опыт театральной драматургии и традиций народных театральных форм, писатель вырабатывает собственную художественную манеру. Художник заимствует тот опыт, который соответствует его эстетическим воззрениям и запросам современности, трансформирует его в соответствии с новой действительностью. Драматург, наряду с широким использованием художественных и выразительных средств, применяемых в практике мирового театра, экспериментирует с целым набором собственных открытий: актерская имп- 
ровизация и лицедейство, пантомима и игра с масками, театр в театре. В поисках максимальной выразительности драматургической peчи Фараг обращается к языковым богатствам народного и литературного языка. Художественное своеобразие драматургии Альфреда Фарага
- это путь индивидуальных исканий писателя. Своим творчеством Фараг пытался вскрывать истинное содержание многих жизненных явления, заостряя внимание на противоречия современного мира, делая их более зримыми, конкретными, рельефными.

\section{Литература}

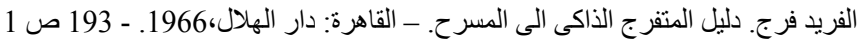

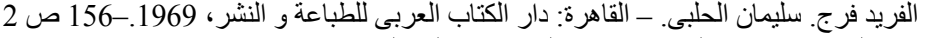

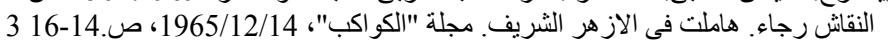

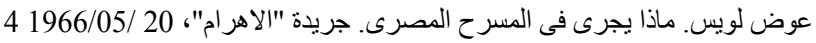

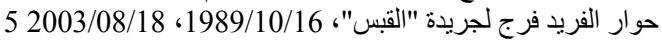

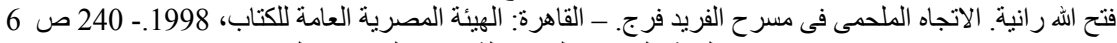

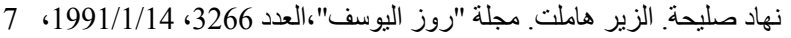

8 Современная арабская литература. - М.: Вост.Лит., 1960. - 192 с.

9 Бертольд Брехт. Пьесы. - М.: Искусство, 1963. - Т. 1.

10 Кирпиченко В.Н., Сафронов В.В. История египетской литературы. ХІХ - XX вв. - М.: Восточная литература, 2002. T. 1. -408 c.

11 Молодцова М. Луиджи Пиранделло. - Л.: Искусство, 1982. - 212 с.

12 Хализев В.Е. Теория литературы. - М.: Высшая школа, 2000. - 383 с.

13 Эсалнек А.Я. Основы литературоведения. Анализ художественного текста: учеб. пособие. - М.: Флинта; Наука, 2004.

\section{References}

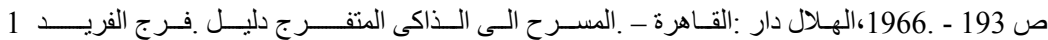

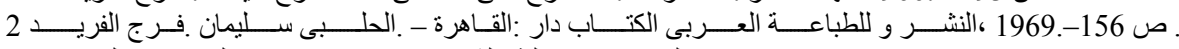

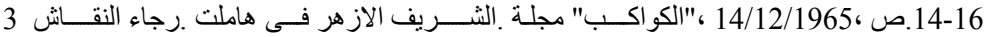

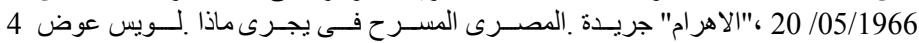

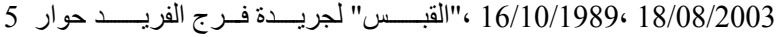

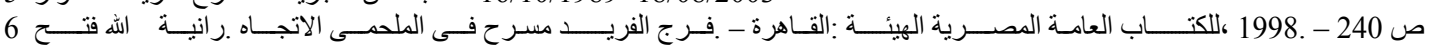

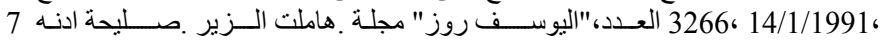

8 Sovremennaja arabskaja literatura. - M.: Vost.Lit., 1960. - $192 \mathrm{~s}$.

9 Bertol'd Breht. P'esy. - M.: Iskusstvo, 1963. - T. 1.

$408 \mathrm{~s}$.

10 Kirpichenko V.N., Safronov V.V. Istorija egipetskoj literatury. HIH - HH vv. - M.: Vostochnaja literatura, 2002. T. 1. -

11 Molodcova M. Luidzhi Pirandello. - L.: Iskusstvo, 1982. - $212 \mathrm{~s}$.

12 Halizev V.E. Teorija literatury. - M.: Vysshaja shkola, 2000. - $383 \mathrm{~s}$.

13 Jesalnek A.Ja. Osnovy literaturovedenija. Analiz hudozhestvennogo teksta: ucheb. posobie. - M.: Flinta; Nauka, 2004. 